\title{
Expression of Klebsiella nif and his Genes in Salmonella typhimurium
}

\author{
By J. R. POSTGATE AND V. KRISHNAPILLAI* \\ Agricultural Research Council, Unit of Nitrogen Fixation, \\ University of Sussex, Brighton BNI $9 Q J$
}

(Received I2 August 1976)

\section{SUMMAR Y}

Derivatives of Salmonella typhimurium carrying F prime or P prime plasmids with Klebsiella nif and his genes had specific nitrogenase activities similar to Klebsiella in selective conditions, even to showing 'hyperinduction' under argon. No evidence was obtained for catabolite repression of normal nif expression but dibutyl cyclic AMP often augmented 'hyperinduction'. In non-selective conditions the Klebsiella his nif determinants were rapidly lost from the plasmids; the low levels of nif expression and temperature-sensitive his expression previously reported were probably due to ready loss of his nif in the test conditions used.

\section{INTRODUCTION}

The ability of Salmonella typhimurium to accept and express plasmids carrying the nif genes of Klebsiella pneumoniae was reported briefly by Cannon, Dixon \& Postgate (1976). The ability is consistent with the substantial evidence that expression of nitrogen fixation (nif) genes is regulated by a mechanism which has much in common with a system for regulation of utilization of histidine studied by Magasanik and his colleagues. This system, which is present in $K$. aerogenes, $S$. typhimurium and Escherichia coli, regulates the use of several other sources of fixed nitrogen (proline, urea, nitrate, etc.); it is based on the ability of the enzyme glutamine synthetase to act as an activator of the genes for histidine utilization (hut) as well as performing its physiological function as an enzyme, provided it is in its deadenylylated form (see Magasanik et al., 1974).

Certain details of the regulation of hut by fixed nitrogen differ between $S$. typhimurium and $K$. aerogenes. In both organisms, gene expression is repressed by ammonium ions and glucose, but in $K$. aerogenes $\mathrm{w}-70$, starvation of fixed nitrogen releases hut from both catabolite repression and $\mathrm{NH}_{4}{ }^{+}$repression, whereas it is not released from catabolite repression in $S$. typhimurium strain I5-59 in comparable conditions (Brill \& Magasanik, I969). Catabolite repression of hut in $K$. aerogenes can be overcome by adding cyclic AMP or by use of non-repressing substrates. After $S$. typhimurium hut genes have been transferred to $K$. aerogenes on an $\mathrm{F}$ prime plasmid, they follow the $K$. aerogenes pattern of regulation (Prival \& Magasanik, I97I). The possibility therefore arises that expression of $K$. pneumoniae nif in S. typhimurium may also follow a changed regulatory pattern; a precedent for changed expression characteristics in the new genetic background seemed also to arise since histidine biosynthesis governed by $K$. pneumoniae his genes apparently became temperature-sensitive in S. typhimurium (Cannon et al., 1976). This paper reports further experiments on the expression of Klebsiella nif and his genes in Salmonella.

* Present address: Department of Genetics, Monash University, Clayton, Victoria 3168, Australia. 25 
Table I. Bacteria and plasmids

\begin{tabular}{|c|c|c|c|}
\hline \multicolumn{2}{|c|}{ Bacterial strain } & Markers & Source or reference \\
\hline \multicolumn{4}{|c|}{ Klebsiella pneumoniae } \\
\hline $\begin{array}{l}\text { Escherichia } \\
\text { JC5466 }\end{array}$ & & $\operatorname{trp}$ recA56 his spc & N. Willetts \\
\hline $\begin{array}{l}\text { Salmonella } t \\
\text { LT7-I201 } \\
\text { UNF602 } \\
\text { VKSI to } 4\end{array}$ & himurium & $\begin{array}{l}\text { his } \Delta \text { str } \\
\text { str } \\
\text { str }\end{array}$ & $\begin{array}{l}\text { S. B. Primrose } \\
\text { LT7-I 20I (FN68); Cannon et al. (I976) } \\
\text { LT7-I 20I (RP4I); this laboratory }\end{array}$ \\
\hline Plasmids & Markers & Compatibility group & Source or reference \\
\hline $\begin{array}{l}\text { FN68 } \\
\text { RP4I }\end{array}$ & $\begin{array}{l}\text { met } G r f b \\
r f b \text { gnd } h\end{array}$ & $\begin{array}{ll}\text { is nif shiA } \mathrm{Cb} & \mathrm{F} \\
\text { shiA } \mathrm{Cb} \mathrm{Km} \mathrm{Tc} & \mathrm{P}\end{array}$ & $\begin{array}{l}\text { Cannon et al. (1976) } \\
\text { Dixon, Cannon \& Kondorosi (1976) }\end{array}$ \\
\hline
\end{tabular}

Symbols for drug resistance determinants: $\mathrm{Km}$, kanamycin; $\mathrm{Tc}$, tetracycline; $\mathrm{Cb}$, Carbenicillin. Symbols for chromosomal markers are those of Taylor \& Trotter (1972).

\section{METHODS}

Bacterial strains and plasmids are listed in Table $\mathrm{r}$. Complete medium was Oxoid no. 2 nutrient broth supplemented where necessary with $2 \%$ (w/v) Difco Bacto-agar. Minimal medium was Davis \& Mingioli (1950) mineral salts; $\mathrm{NH}_{4}{ }^{+}$-free medium used for culture in nitrogen-fixing conditions was NFDM (Cannon et al., 1974)' containing Casamino acids (I00 $\mu \mathrm{g} \mathrm{ml}^{-1}$ ). Antibiotics and supplements used were prescribed by Cannon et al. (1976) except that spectinomycin, used to counterselect salmonella in certain mating experiments, was used at $600 \mu \mathrm{g} \mathrm{ml}^{-1}$. Cannon et al. (1976) also described the procedures for conjugation using $\mathrm{F}$ prime and $\mathrm{P}$ prime plasmids. Viable counts were performed by diluting cultures in saline phosphate buffer, spreading on agar plates and incubating to constant count. The plating efficiency of the salmonella strain used here was always 20 to $40 \%$ lower on minimal agar than on nutrient agar; counts on nutrient agar were systematically about $20 \%$ lower at $30^{\circ} \mathrm{C}$ than at $37^{\circ} \mathrm{C}$ (see Table 4 , expt $\mathrm{I}$ ).

Nitrogenase activity. Cannon et al. (1976) described the detection of nitrogenase by the acetylene test using Pankhurst tubes and the special procedure used with $S$. typhimurium to assess specific activities. Protein was estimated with the Folin-Ciocalteau reagent (Lowry et al., I95I) with bovine serum albumin as standard, but for most tests, protein content was judged from absorbance using a curve relating $E_{540}$ to bacterial protein.

Reagents. Sodium $N^{6}, O^{2}$-dibutyryl adenosine $3^{\prime}: 5^{\prime}$-cyclic monophosphate (dibutyl cyclic AMP) was obtained from Sigma.

\section{RESULTS}

Nitrogen-fixing salmonellae

Salmonella typhimurium UNF602 was a derivative of LT7-I20I carrying the $\mathrm{F}^{\prime}$ his nif plasmid FN68. The preparation of UNF602 and its ability to fix acetylene and ${ }^{15} \mathrm{~N}_{2}$ was reported by Cannon et al. (1976). Salmonella typhimurium vKsI was one of four $\mathrm{His}^{+}$transconjugants from a surface mating of $E$. coli JC5466 (RP4I) with $S$. typhimurium LT7-I2OI, all of which showed positive acetylene-reducing activity in qualitative tests in Pankhurst tubes. Unlike UNF602, in which the fertility determinants of the $F$ prime plasmid were repressed, VKSI retained donor activity and transferred RP4I readily to $E$. coli JC5466 in surface matings. Irradiation of the parent strain LT7-I20I with u.v.-light or treatment with $N$-methyl- $N^{\prime}$-nitro- $N$-nitrosoguanidine gave no $\mathrm{Nif}^{+}$derivatives on anaerobic plates or in 
Table 2. Specific acetylene-reducing activities of nitrogen-fixing Salmonella typhimurium UNF602

For full test procedure, see Cannon et al. (1975). Cultures from minimal glucose agar plates were inoculated into Pankhurst tubes containing minimal medium with $100 \mu \mathrm{g}$ Casamino acids $\mathrm{ml}^{-1}$ as sole nitrogen source and carbon source at $I \%(w / v)$. Samples were removed for assay aseptically and anaerobically after 18 to $24 \mathrm{~h}$ at $30^{\circ} \mathrm{C}$ for acetylene reduction assay lasting 60 to $120 \mathrm{~min}$ at $30^{\circ} \mathrm{C}$. Specific activities are expressed as $\mathrm{nmol} \mathrm{C}_{2} \mathrm{H}_{4}$ formed (mg bacterial protein) ${ }^{-1} \mathrm{~min}^{-1}$. Klebsiella pneumoniae gave specific activities of 30 to 60 in comparable conditions with glucose.

$\begin{array}{lc}\text { Growth substrate } & \text { Specific activity } \\ \text { Glucose } & 29-60 \\ \text { Mannitol } & 59 \\ \text { Rhamnose } & 33 \\ \text { Arabinose } & 60\end{array}$

No growth was observed with glycerol, xylose, sodium gluconate or sodium lactate in Pankhurst tubes.

Table 3. 'Hyperinduction' of nitrogenase activity of S. typhimurium UNF602 under argon and the effect of cyclic $A M P$

Samples ( $\mathrm{I} \mathrm{ml}$ ) from a Pankhurst tube culture ( 8 to $24 \mathrm{~h}$ ) in glucose NFDM medium were injected into $\mathrm{I} 8 \mathrm{ml}$ Warburg manometer flasks containing $\mathrm{I} \mathrm{ml}$ fresh medium with or without 0.8 to I $\mu \mathrm{mol}$ dibutyl cyclic AMP under argon with a pyrogallol plug in the side arm. After pre-incubating for up to $3.7 \mathrm{~h}$ at $30^{\circ} \mathrm{C}$, acetylene $(2 \mathrm{ml})$ was injected and samples were taken for analysis by gas chromatography at intervals up to $\mathrm{I} 20 \mathrm{~min}$ at $30^{\circ} \mathrm{C}$. Nitrogenase activities are expressed as $\mathrm{nmol}$ $\mathrm{C}_{2} \mathrm{H}_{4}$ (mg bacterial protein) ${ }^{-1} \mathrm{~min}^{-1}$.

\begin{tabular}{cccc} 
Expt & $\begin{array}{c}\text { Pre-incubation period } \\
\text { (h) }\end{array}$ & Cyclic AMP & Nitrogenase activity \\
I & 3.7 & + & 136 \\
& & - & 70 \\
2 & 3.5 & + & 195 \\
3 & 2 & - & 154 \\
& & + & 119 \\
4 & I & - & II9 \\
5 & & - & 98 \\
$6^{*}$ & 0 & - & 74.5 \\
& 3.5 & + & 75 \\
\hline
\end{tabular}

+ , Present; - , absent.

* Control experiment in $\mathrm{N}_{2}$. Growth from 25 to $44 \mu \mathrm{g}$ bacterial nitrogen $\mathrm{ml}^{-1}$ took place during preincubation.

Pankhurst tubes with $20 \mu \mathrm{g}$ histidine $\mathrm{ml}^{-1}$ as sole nitrogen source, confirming the unlikelihood of cryptic nif genes existing in this microbe.

Specific nitrogenase activity. Early experiments had given relatively low and variable specific activities in UNF602 (Cannon et al., 1976) and comparable tests with vKS I also gave low values. However, extremely low activity of organisms stored on nutrient agar alerted us to the possibility that the medium on which the parent population had been grown might influence the apparent activity. Table 2 records specific activities for populations of UNF602 taken from Pankhurst tubes which had been inoculated from cultures on minimal agar: the values were comparable to those in $K$. pneumoniae and little affected by change from glucose to other carbon substrates.

Effect of cyclic AMP. The equivalence of the specific activities of cultures with glucose or other carbon substrates suggests that $K$. pneumoniae nif genes are not subject to catabolite repression in S. typhimurium. The experiments of Streicher, Gurney \& Valentine (1972) with 


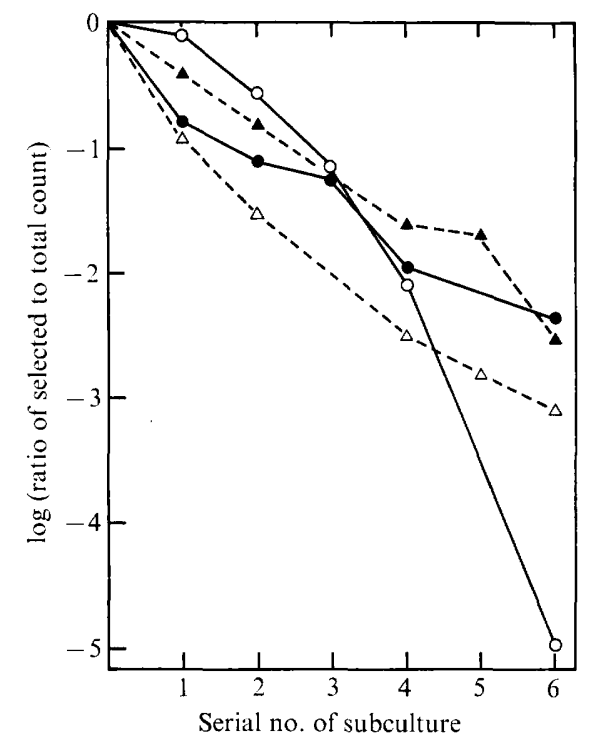

Fig. I. Loss of $\mathrm{His}^{+}$phenotype in non-selective conditions from S. typhimurium LT7-1 20I carrying plasmids with $K$. pneumoniae his and nif genes. Serial subcultures of S. typhimurium strains UNF602 and VKSI in nutrient broth at 30 and $37^{\circ} \mathrm{C}$ were counted on non-selective (nutrient agar) and His $^{+}$-selective (glucose/salts) plates at $30^{\circ} \mathrm{C}$ over six passages. Initial populations counted contained $4 \times 10^{8}$ to $7 \times 10^{8}$ viable cells $\mathrm{ml}^{-1}$; each subculture was an approximately $\mathrm{r} / 1 \mathrm{O}^{3}$ dilution of the parent. $\bigcirc$, UNF602 at $37^{\circ} \mathrm{C} ; \triangle$, UNF602 at $30^{\circ} \mathrm{C} ; 0$, vKsI at $37^{\circ} \mathrm{C} ; \Delta$, vKsI at $30^{\circ} \mathrm{C}$. Dashed and continuous lines distinguish temperatures.

adenylcyclase mutants show that nif expression in $K$. pneumoniae does not involve cyclic AMP. Nevertheless, cyclic AMP can relieve catabolite repression of hut in nitrogen-limited $K$. aerogenes so it was of interest to test for an effect of added cyclic AMP on nif expression in the new genetic background. The concentration of dibutyl cyclic AMP chosen was that effective in $K$. aerogenes (Calcott \& Postgate, I972). Samples (I ml) from a Pankhurst tube were injected into two Warburg vessels set up under argon without acetylene but with I ml of fresh medium; one vessel contained in addition 0.8 to I $\mu \mathrm{mol}$ dibutyl cyclic AMP. After incubation for up to $3.7 \mathrm{~h}$ to allow further derepression of nif, acetylene was injected and samples were taken for analysis by gas chromatography at intervals for a further $120 \mathrm{~min}$. Table 3 records the results of several such experiments. Incubation of the suspensions under argon caused augmentation of nitrogenase activity; similar augmentation was observed previously in nitrogen-limited continuous cultures of nitrogen-fixing bacteria under argon (Daesch \& Mortensen, I968, with Clostridium pasteurianum; Dalton \& Postgate, 1969, with Azotobacter chroococcum). This 'hyperinduction' of nitrogenase activity was also observed with $K$. pneumoniae M5a I in the conditions used here to test $S$. typhimurium. A specificactivity in the region of I 80 to $200 \mu \mathrm{mol} \mathrm{C}_{2} \mathrm{H}_{4} \mathrm{mg}^{-1} \mathrm{~min}^{-1}$ seemed to be the maximum level of nif expression in both $K$. pneumoniae and $S$. typhimurium; dibutyl cyclic AMP did, in most experiments, augment sub-maximal nitrogenase activities, but the effect was not sufficiently consistent to permit the conclusion that catabolite repression was operating in nif expression.

\section{Stability of nif plasmids in S. typhimurium}

Six successive cultures in nutrient broth of strains UNF602 and VKSI were counted on nutrient agar and minimal glucose medium (the latter selects for the his determinant on the 
Table 4. Apparent temperature sensitivity of $K$. pneumoniae his genes in S. typhimurium

Plate counts on flask cultures of strains of S. typhimurium, mostly carrying his nif plasmids (for details, see text) were made at 30 and $37^{\circ} \mathrm{C}$ on nutrient agar (NA), glucose minimal agar (MM) and sometimes glucose minimal agar plus $20 \mu \mathrm{g}$ L-histidine $\mathrm{ml}^{-1}$ (MM-his). LT7-I $20 \mathrm{I}$ is the parent strain without plasmids; VKSI-I is a derivative of VKSI picked after growth on MM at $37^{\circ} \mathrm{C}$.

\begin{tabular}{|c|c|c|c|c|c|c|c|}
\hline \multirow[b]{3}{*}{ Expt } & \multirow[b]{3}{*}{ Strain } & \multicolumn{5}{|c|}{$10^{-8} \times$ Viable count } & \\
\hline & & \multicolumn{3}{|c|}{ At $30^{\circ} \mathrm{C}$} & \multicolumn{3}{|c|}{ At $37^{\circ} \mathrm{C}$} \\
\hline & & NA & MM & MM-his & NA & MM & MM-his \\
\hline I & LT7-I 2OI* & $8 \cdot 8$ & - & $7 \cdot 2$ & $9 \cdot 5$ & - & $6 \cdot 5$ \\
\hline 2 & UNF602 & $7 \cdot 25$ & $3 \cdot 5$ & - & 7 & 0.16 & - \\
\hline 3 & UNF602 & $7 \cdot 8$ & $1 \cdot 5$ & $2 \cdot 6$ & - & - & - \\
\hline 4 & VKSI & $2 \cdot 85$ & 0.52 & - & $3 \cdot 05$ & 0.17 & 一 \\
\hline 5 & VKSI* & $2 \cdot 95$ & $2 \cdot 05$ & - & $2 \cdot 76$ & 0.01 & - \\
\hline 6 & VKSI & $\mathrm{I} \cdot 75$ & $0 \cdot 14$ & 0.95 & - & 一 & - \\
\hline 7 & VKSI-I & - & 0.75 & $\mathrm{I} \cdot 8 \mathrm{I}$ & $2 \cdot 76$ & $<0.0 \mathrm{I}$ & 一 \\
\hline
\end{tabular}

* Parent cultures from nutrient broth; all others were from liquid MM.

two his nif plasmids). Figure I records the ratio of the selected to unselected counts for broth cultures at 30 and $37^{\circ} \mathrm{C}$ : the his nif genes of both plasmids were rapidly lost in S. typhimurium. On the sixth passage, counts were also made on media selecting for the drug resistance markers of the two plasmids: carbenicillin for FN68; carbenicillin and kanamycin for RP4I. The resistance determinants of RP4, the parent plasmid of RP4I, were stably conserved over six passages at either temperature but that of FN68 was partially lost: by a factor of 8 at $30^{\circ} \mathrm{C}$ and a factor of 33 at $37^{\circ} \mathrm{C}$.

\section{Temperature sensitivity of K. pneumoniae his genes in S. typhimurium}

Strain UNF602 (and other derivatives carrying FN68) expressed his at $30^{\circ} \mathrm{C}$ but not at $37^{\circ} \mathrm{C}$ when tested from a parent stock in nutrient broth, and no $\mathrm{His}^{+}$transconjugants were observed in $E$. coli $\times S$. typhimurium matings if selection was at $37^{\circ} \mathrm{C}$ instead of $30^{\circ} \mathrm{C}$ (Cannon et al., 1976). Further study of temperature sensitivity in both UNF602 and VKSI showed that it was less pronounced if the parent stock was maintained on minimal medium but was still observed. It was quantitative: counts on a minimal medium at $37^{\circ} \mathrm{C}$ were lower by $4^{-}$to 200 -fold than at $30^{\circ} \mathrm{C}$ (Table 4 , expts $2,4,5$ ).

The temperature sensitivity could be observed qualitatively in streaks spread by a conventional loop from a given population and incubated at the two temperatures. Since apparently temperature-tolerant strains appeared, Io such derivatives of VKSI were isolated. All Io showed qualitative evidence of temperature sensitivity as streaks on minimal agar; one, VKSI-I, was checked quantitatively and was as temperature-sensitive as VKSI (Table 4, expt 7).

If apparent temperature sensitivity is due to rapid loss of his nif determinants from the plasmid at $37^{\circ} \mathrm{C}$, comparable loss might be expected at $30^{\circ} \mathrm{C}$, at which temperature counts on plates of minimal medium with added histidine ought to be greater than on plates without histidine. Histidine augmented the plate counts of UNF602, VKS I and VKSI-I at $30^{\circ} \mathrm{C}$ (Table 4 , expts $3,6,7)$ though not, as with the parent strain, to the value obtained on nutrient agar (expts I, 3,6). 


\section{DISCUSSION}

Salmonella typhimurium LT7-I20I expressed plasmid-borne $K$. pneumoniae M5a I nif genes as effectively as does the parent $K$. pneumoniae according to the acetylene reduction test. Ammonium repression was displayed (Cannon et al., I 976), and so was 'hyperinduction' under argon. Earlier reports that the level of nif expression is low in Salmonella must be attributed to ready dissociation and loss of the $K$. pneumoniae component of the plasmid DNA in the non-selective conditions used to maintain the parent stock. If selection for His ${ }^{+}$was maintained throughout, low levels of nif expression were not observed.

Though the regulation of nif has much in common with that of hut, and hut shows catabolite repression in S. typhimurium I5-59 (Brill \& Magasanik, 1969), no comparable repression was observed with $K$. pneumoniae nif in $S$. typhimurium LT7. An effect of cyclic AMP sometimes occurred during 'hyperinduction' but was not consistently observed. 'Hyperinduction' of nitrogenase expression complicates the interpretation of derepression experiments with intact, growing bacteria since one does not know whether it reflects a true derepression (i.e. increased nitrogenase syntheses) or simply more effective mobilization of ATP or reductant; the phenomenon needs more detailed study in Klebsiella before its significance in Salmonella can be usefully discussed.

It seems, however, that Klebsiella nif genes are fully expressed and show all the phenotypic characters in $S$. typhimurium LT7 that they do in the parent $K$. pneumoniae. A preliminary report (Bloom, Streicher \& Tyler, 1976) that the hut system of S. typhimurium 15-59 does not respond to Salmonella glutamine synthetase, though Salmonella glutamine synthetase can activate hut in Klebsiella, raises the question of whether the expression of Klebsiella nif genes in Salmonella indicates reponse to Salmonella glutamine synthetase or changed promoter specificity. Tests for expression of nif in strain I 5-59 would be interesting in this context; the relation of the regulation pattern of the hut system in $15-59$ to that in LT7, the strain used here, is not known, but it is different from that in LT2 (Meiss, Brill \& Magasanik, 1969).

The apparent temperature sensitivity of the expression of Klebsiella his genes in S. typhimurium LT7 can also be explained in terms of dissociation of Klebsiella DNA from the plasmids. Loss of his was clearly demonstrated in non-selective conditions (Fig. I); loss of drug resistance determinants from the plasmids did not occur with $\mathrm{RP}_{4} \mathrm{I}$ and was considerably less than the loss of his nif from FN68. Augmentation of counts on minimal media by histidine provides evidence for loss of his at the seemingly permissive temperature even in selective conditions. Figure I does not permit any generalization to be made about the relative rates of loss of Klebsiella determinants at the two temperatures tested, nor about the stability of the Klebsiella component in the two plasmids. It is possible, however, that the initial rate of loss was higher at $37^{\circ} \mathrm{C}$ and that this temperature thus appeared 'nonpermissive' for the bulk of the population and could, in primary selection for $\mathrm{His}^{+}$salmonellae, lead to loss of all positive transconjugants. The fact that presumptive temperaturetolerant variants showed unchanged responses to temperature suggests an operational explanation along these lines rather than a new mode of expression of Klebsiella genes in the Salmonella genetic background.

The specific instability of Klebsiella his nif determinants when the plasmids are in Salmonella is a curious phenomenon: why should the Klebsiella DNA dissociate particularly easily? This has a bearing on the use of constructed plasmids for other intergeneric transfers: for practical reasons, positive selection for His or Nif is desirable and incubation for transconjugants or transformants should be at a lower temperature than would be necessary if 
drug resistance were the selected marker. For more stable nitrogen-fixing transconjugants, means may be needed to induce chromosomal integration of his nif such as occurred in E. coli strain CM7 (Cannon et al., I974).

Salmonella typhimurium LT7-I20I is mildly pathogenic and has been the cause of laboratory infections (G. Humphries, personal communication). Because the combination of drug resistance determinants on $\mathrm{RP}_{4} \mathrm{I}$ includes two agents effective against salmonellosis, all derivatives carrying this plasmid have now been destroyed.

We are grateful to R. A. Dixon for detailed discussion of this work while it was in progress and for critical evaluation of the manuscript.

\section{REFERENCES}

Bloom, F. R., Streicher, S. L. \& Tyler, B. M. (1976). Activation of histidase synthesis by Salmonella typhimurium glutamine synthetase. Abstract of the Meeting of the American Society for Microbiology KI45, p. 160 . Washington: American Society for Microbiology.

BRILL, W. J. \& MAGASANIK, B. (I969). Genetic and metabolic control of histidase and urocanase in Salmonella typhimurium strain I 5-59. Journal of Biological Chemistry 224, 5392-5402.

CALCOTt, P. H. \& PostGATE, J. R. (1972). On substrate-accelerated death in Klebsiella aerogenes. Journal of General Microbiology 70, II 5-1 22.

Cannon, F. C., Dixon, R. A., Postgate, J. R. \& Primrose, S. B. (1974). Chromosomal integration of Klebsiella nitrogen fixation genes in Escherichia coli. Journal of General Microbiology 80, 227-234.

Cannon, F. C., Dixon, R. A. \& Postgate, J. R. (1976). Derivation and properties of F-prime factors in Escherichia coli carrying nitrogen fixation genes from Klebsiella pneumoniae. Journal of General Microbiology 93 , I I I-I 25.

Daesch, G. \& MoRTEnSEN, L. E. (1968). Sucrose catabolism in Clostridium pasteurianum and its relation to $\mathrm{N}_{2}$ fixation. Journal of Bacteriology 96, 346-35I.

Datton, H. \& Postgate, J. R. (I969). Growth and physiology of Azotobacter chroococcum in continuous culture. Journal of General Microbiology 56, 307-319.

Davis, B. D. \& MingIoli, E. S. (I950). Mutants of Escherichia coli requiring methionine or vitamin BI2. Journal of Bacteriology 60, 1 7-28.

Dixon, R. A., CANNON, F. C. \& KondoRosi, A. (1976). Construction of a P plasmid carrying nitrogen fixation genes from Klebsiella pneumoniae. Nature, London 260, 268-27I.

Lowry, O. H., Rosebrough, N. J., Farr, A. L. \& Randall, R. J. (I95I). Protein measurement with the Folin phenol reagent. Journal of Biological Chemistry 193, 265-275.

Magasanik, B., Prival, M. J., Brenchley, J. E., Tyler, B. M., Deleo, A. B., Streicher, S. L., Bender, R. A. \& PARIs, C. G. (I974). Glutamine synthetase as a regulator of enzyme synthesis. Current Topics in Cellular Regulation 8, I19-138.

MeISS, H. K., BRILL, W. J. \& MAGASANIK, B. (1969). Genetic control of histidine degradation in Salmonella typhimurium strain LT-2. Journal of Biological Chemistry 244, 5382-5391.

Prival, M. J. \& MAGASANIK, B. (I97I). Resistance to catabolite repression of histidase and proline oxidase during nitrogen-limited growth. Journal of Biological Chemistry 246, 6288-6296.

Streicher, S. L., Gurney, E. G. \& Valentine, R. C. (1972) The nitrogen fixation genes. Nature, London 239, 495-499.

TAYLOR, A. L. \& TROTTER, C. D. (1972). Linkage map of Escherichia coli strain K-I 2. Bacteriological Reviews 36, 504-524. 